\title{
A MORPHOMETRIC STUDY OF SHEEP REARED IN NORTH-EAST ALGERIAN
}

\author{
ANALYSE DISCRIMINANTE DES OVINS DANS LA RÉGION EST DE L'ALGÉRIE
}

Dekhili, M.

Département d'Agronomie. Université Sétif 1. Sétif. Algérie. *dekhili48@yahoo.fr

\section{AdDitional KEYWORDS}

Body measurements. Canonical analysis. Characterization. Correspondance analysis. Discriminant analysis. Multivariate analysis. Quantitative traits. Qualitative traits.

\section{SUMMARY}

A total of 347 adult female sheep from the Sétif area (Algeria), were investigated for thirteen qualitative morphological traits and eighteen body measurements. Sampling included populations from each of three environmental areas: Northern, Central and Southern. Coefficients of variation of the 18 body measurements ranged from $4.4 \%$ to $34.3 \%$, showing high heterogeneity. Canonical analyses showed that differences in body measurements between the three populations were large $(p<0.0001)$. Only nine traits were significant at the stepwise discriminant and the others were removed from the final model. Mahalanobis distances were found to be very large: 10.53 between North and South, 9.23 between Centre and South and 7.59 between North and Centre. Discriminant analysis showed that most of the populations were classified into their environmental-area: North (74.59\%), Center $(84.0 \%)$ and South ( $97.14 \%)$. Correspondence analysis indicated large differences between populations and uniformity within populations. The information produced will constitute the basis for further characterization and will facilitate the development of conservation strategies for Algerian sheep-populations.

\section{RÉSUMÉ}

La caractérisation de 347 brebis adultes a été réalisée dans la région de Sétif (Algérie). L'échantillonnage a concerné trois sites environ-

\section{MOTS CLÉS ADITIONNELLES}

Mesures corporelles. Analyse canonique. Caractérisation. Analyse des correspondances. Analyse discriminante. Analyse multivariée. Variables quantitatives. Variables qualitatives.

nementaux: Nord, Centre et Sud. Selon les résultats obtenus, les coefficients de variations ont varié de $4,4 \%$ à $34,3 \%$, inférant ainsi une large hétérogénéité. L'analyse canonique a fait ressortir de larges et significatives $(p<0,0001)$ différences pour les mesures corporelles. Seulement huit variables ont été significatives au pas à pas discrimination, par contre les autres variables ont été éliminées du modèle final. Les distances de Mahalanobis, ont été aussi significatives entre les trois zones. Concernant l'analyse discriminante, la plus-part des individus ont été classés dans leur zone d'origine, avec un très faible nombre d'individus mal classé. L'analyse des correspondances, a indiqué de larges différences entre les populations et une large homogénéité intra zone.

\section{INTRODUCTION}

The Algeria sheep population numbers around 23 million heads, where sheep that are a source of income for about 18000 small farmers. Sheep management is carried out under very harsh conditions and with a large variation in flock sizes, they are found in small numbers (4 to 10) or in a large numbers (thousands), depending on breeders and their location, steppe or high plateaux. In Algeria, small ruminants represent a very important national re- 


\section{DEKHILI}

source, and they are reared primarily for meat. Sheep also have a major cultural importance due to their traditional use in rites and celebrations. In the past, there were in Algeria several sheep breeds (Chellig, 1992), well adapted to their respective environments, from North to South. These breeds had (and still have) the ability to tolerate harsh climates, good recovery capacity from draught, suitability to low input systems because of their ability to thrive on poor quality diets, to mate in all seasons and to tolerate long distance walking. Selection is mainly based on qualitative traits which are stature of parents and wool colour. Rams are kept in the flock for 4 to 5 years. No breeding programmes have been implemented to improve productivity of small ruminants and they are bred extensively in traditional conditions (Dekhili and Aggoun, 2007). In spite of its national importance, information on sheep resources of Algeria is scarce, which does not contribute to the characterization of different local genetic types. Due to several problems, no clearly defined breed exist at this moment, actually it is widely accepted in Algeria that native sheep can be divided into their major types according to geographic location and local names. To improve animal productivity and to maintain genetic diversity, solid strategy is needed

Table I. Overall mean( $\mathrm{cm}) \pm$ standard error (SE), coefficient of variation (CV), least squares means (LSM) \pm standard error (SE) of the nineteen body measures in each of the three areas. (Moyennes générales \pm erreur standard, coefficients de variation, moyennes des carrées \pm erreur standard).

\begin{tabular}{|c|c|c|c|c|c|}
\hline $\begin{array}{l}\text { Traits } \\
(\mathrm{cm})\end{array}$ & Overall-means & CV\% & $\begin{array}{c}\text { Northern-area } \\
\text { LSM }\end{array}$ & $\begin{array}{c}\text { Central-area } \\
\text { LSM }\end{array}$ & $\begin{array}{c}\text { Southern-area } \\
\text { LSM }\end{array}$ \\
\hline hl & $22.7 \pm 0.12$ & 8.3 & $21.7^{\mathrm{a}} \pm 0.1$ & $23.9^{b \pm} 0.1$ & $22.5^{5^{ \pm}} 0.3$ \\
\hline el & $18.2 \pm 0.09$ & 8.1 & $17.7^{\mathrm{a} \pm 0.1}$ & $18.9^{b} \pm 0.1$ & $17.9^{\mathrm{a}} \pm 0.2$ \\
\hline ew & $9.0 \pm 0.04$ & 7.9 & $8.8^{b} \pm 0.1$ & $9.3^{a} \pm 0.1$ & $9.0^{b} \pm 0.1$ \\
\hline ed & $11.6 \pm 0.06$ & 8.7 & $10.9^{\mathrm{a}} \pm 0.07$ & $11.7^{b} \pm 0.08$ & $12.1^{c} \pm 0.1$ \\
\hline $\mathrm{nl}$ & $32.2 \pm 0.3$ & 15.1 & $30.8^{b} \pm 0.04$ & $32.9^{a} \pm 0.4$ & $32.7^{a} \pm 0.6$ \\
\hline bl & $103.4 \pm 0.4$ & 6.2 & $103.7^{\mathrm{a}} \pm 0.7$ & $105.3^{a} \pm 0.6$ & $101.3^{\mathrm{a} \pm} 0.9$ \\
\hline $\operatorname{trl}$ & $70.1 \pm 0.3$ & 6.0 & $73.1^{a} \pm 0.3$ & $67.3^{\mathrm{b}} \pm 0.4$ & $69.9^{c} \pm 0.6$ \\
\hline pl & $16.3 \pm 0.08$ & 8.2 & $15.8^{a} \pm 0.1$ & $17.2^{\mathrm{b}} \pm 0.1$ & $15.9^{a} \pm 0.2$ \\
\hline h w & $20.9 \pm 0.10$ & 7.8 & $20.8^{a} \pm 0.1$ & $20.6^{a} \pm 0.1$ & $21.4^{b} \pm 0.2$ \\
\hline cs & $98.8 \pm 0.40$ & 6.6 & $98.4 \pm 0.5$ & $98.2 \pm 0.6$ & $98.3 \pm 0.9$ \\
\hline $\mathrm{cd}$ & $36.8 \pm 0.20$ & 7.2 & $36.6 \pm 0.2$ & $36.3 \pm 0.3$ & $37.6 \pm 0.4$ \\
\hline$c$ w & $28.7 \pm 0.20$ & 12.6 & $27.6^{a} \pm 0.3$ & $28.3^{a \pm} 0.3$ & $30.0^{b} \pm 0.5$ \\
\hline htw & $79.2 \pm 0.20$ & 4.4 & $77.9^{a} \pm 0.3$ & $77.9^{\mathrm{a}} \pm 0.3$ & $81.6^{\mathrm{b}} \pm 0.5$ \\
\hline hs & $78.6 \pm 0.20$ & 4.5 & $77.9^{a} \pm 0.3$ & $78.3^{a} \pm 0.3$ & $79.6^{c} \pm 0.5$ \\
\hline hb & $77.9 \pm 0.20$ & 4.6 & $77.0^{\mathrm{a}} \pm 0.3$ & $77.1^{\mathrm{a} \pm} 0.3$ & $79.6^{b} \pm 0.5$ \\
\hline$s d$ & $38.9 \pm 0.20$ & 7.0 & $39.3 \pm 0.2$ & $38.8 \pm 0.2$ & $38.5 \pm 0.4$ \\
\hline $\mathrm{tl}$ & $38.9 \pm 0.31$ & 12.7 & $40.3^{a} \pm 0.4$ & $38.6^{b} \pm 0.5$ & $38.1^{b} \pm 0.7$ \\
\hline wgt & $47.4 \pm 0.99$ & 34.3 & $52.5^{\mathrm{a}} \pm 1.2$ & $38.3^{\mathrm{b}} \pm 1.5$ & $51.4^{\mathrm{a}} \pm 2.2$ \\
\hline
\end{tabular}

$\mathrm{hl}=$ head length; el= ear length; ew= ear width; ed= eye distance; $\mathrm{nl}=$ neck length; $\mathrm{bl}=$ body length; $\mathrm{trl}=$ trunk length; $\mathrm{pl}=$ pelvis length; hw= hip width; $\mathrm{cs}=$ chest size; $\mathrm{cd}=$ chest depth; $\mathrm{cw}=$ chest width; hw= height at withers; hs= height at sacrum; $h b=$ height at back; $s d=$ side depth; $t=$ tail length; $w g t=$ live weight. ${ }^{a b}$ Areas with different letter differ $(p<0.05)$. 
in order to allow farmers to select or to sell more animals or to create new breeds. The first step of the characterization of Algerian local genetic resources is to assess variation in morphological traits (Delgado et al., 2001). Many authors have suggested use of multifactorial analysis for morphological traits in order to assess phenotypic variation within and between small ruminant population (Traoré et al., 2008a, b; Yakubu et al., 2010; Legaz et al., 2011; Yakubu, 2011 et Dekhili et al., 2013).

\section{MATERIALSAND METHODS}

ENVIRONMENTAL AREAS AND SHEEP POPULATIONS

The high plateaux of Sétif is divided naturally into three environmental areas according to climate conditions, altitude, type of soil and vegetation.

Northern area: located between 1500 to $2000 \mathrm{~m}$ of altitude, with an annual rainfall $<700 \mathrm{~mm}$, with low temperatures varying from -5 to $20^{\circ} \mathrm{C}$ and grassy, bushy and

Table II. Frequency of each class of qualitative traits scored in Sétif area sheep and percentage for each qualitative traits in brackets. (Fréquence de chaque classe des variables qualitatives notées dans la région de Sétif).

\begin{tabular}{|c|c|c|c|c|c|}
\hline Traits & Class level & Northern-area & Central-area & Southern-area & $\begin{array}{l}\text { Overall mean } \\
\text { frequency }(\%)\end{array}$ \\
\hline \multirow[t]{2}{*}{ hc } & white & 166 (94.86) & 102 (83.61) & $30(60.0)$ & 298 (85.88) \\
\hline & mixture & $9(5.14)$ & $20(40.0)$ & $20(40.0)$ & 49 (14.12) \\
\hline \multirow[t]{2}{*}{ eyf } & small & - & $5(4.10)$ & - & $5(1.44)$ \\
\hline & bigger & $175(100.0)$ & $117(95.90)$ & $50(100.0)$ & $342(98.56)$ \\
\hline \multirow[t]{2}{*}{ ef } & vertical & $50(28.57)$ & $114(93.44)$ & $50(100.0)$ & 214 (61.67) \\
\hline & dropping & $125(71.43)$ & $8(6.56)$ & - & 133 (38.83) \\
\hline \multirow[t]{2}{*}{$\mathrm{pf}$} & right & $174(99.43)$ & $120(98.36)$ & $50(100.0)$ & 344 (99.14) \\
\hline & arched & $1(0.57)$ & $2(1.64)$ & - & $3(0.86)$ \\
\hline \multirow[t]{2}{*}{ w c } & white & $168(96.0)$ & $107(87.70)$ & $29(58.0)$ & $304(87.61)$ \\
\hline & mixture & 7 (4.0) & 15 (12.30) & $21(42.0)$ & 43 (12.39) \\
\hline \multirow[t]{2}{*}{ fe } & semi-abundant & $49(28.0)$ & $32(26.23)$ & $22(44.0)$ & $103(29.68)$ \\
\hline & abundant & $126(72.0)$ & $90(73.77)$ & $28(56.0)$ & $244 \mathrm{n}(70.32)$ \\
\hline \multirow[t]{3}{*}{$\mathrm{ft}$} & closed & $154(88.0)$ & 101 (82.79) & $43(86.0)$ & 298 (85.88) \\
\hline & open & $21(12.0)$ & 21 (17.21) & 7 (14.0) & 49 (14.12) \\
\hline & thin & $47(26.86)$ & 65 (53.28) & $29(58.0)$ & $141(40.63)$ \\
\hline \multirow[t]{3}{*}{ tt } & thick & $26(1.14)$ & 22 (18.03) & $1(2.0)$ & $25(7.20)$ \\
\hline & midddle & $126(72.0)$ & 35 (28.69) & $20(40.0)$ & $181(52.16)$ \\
\hline & good & $6(3.43)$ & 28 (22.95) & $7(14.0)$ & 41 (11.82) \\
\hline \multirow[t]{2}{*}{ bc } & middle & $164(93.71)$ & $64(52.46)$ & $21(42.0)$ & $249(71.76)$ \\
\hline & bad & $5(2.86)$ & $30(24.59)$ & $22(44.0)$ & $57(16.43)$ \\
\hline \multirow[t]{2}{*}{ ud } & developped & $167(95.43)$ & $46(37.70)$ & $25(50.0)$ & $256(73.78)$ \\
\hline & non-developped & $8(4.57)$ & $76(62.30)$ & $25(50.0)$ & $91(26.22)$ \\
\hline \multirow[t]{2}{*}{$b f$} & right & $159(90.86)$ & $74(60.66)$ & $37(74.0)$ & $270(77.81)$ \\
\hline & curved & $16(9.14)$ & $48(39.34)$ & $13(26.0)$ & 77 (22.19) \\
\hline
\end{tabular}

$\mathrm{hc}=$ head colour; $\mathrm{hf}=\mathrm{horn}$ form; ef= eye form; ef= ear form; $\mathrm{pf}=$ profile form; $\mathrm{wc}=$ fleece colour; fe $=$ fleece extent; $\mathrm{ft}=$ fleece texture; $\mathrm{tt}=$ tail texture; $\mathrm{bc}=$ body conformation, $\mathrm{Ic}=$ legs colour; $\mathrm{ud}=$ udder development; $\mathrm{bf}=$ back form.

The incidence of all the analyzed traits varied significantly $\left(\chi^{2}\right.$ test at $\left.p<0.05\right)$ among environmental areas. 


\section{DEKHILI}

shrubby vegetation, usually quite sparse, with ligneous species. Soils are black, hygroscopic and mainly of clay.

Central area: located between 900 to 1200 m of altitude, with annual rainfall $<400$ $\mathrm{mm}$. Temperatures vary from -1 to $25^{\circ} \mathrm{C}$. Vegetation is mainly based on fallow ground or stubble of cereals. Soils are more salty with brown colour.

Southern area: located at $800 \mathrm{~m}$ of altitude with annual rainfall $<250 \mathrm{~mm}$. Vegetation is quite sparse, with ligneous species: Stipatenacissima and Artemesiaherbaalba. Soils are more limestone, with white colour and salty. Temperatures vary from -1 to $35^{\circ} \mathrm{C}$.

The three environmental areas described above are habitats of the sheep populations concerned in this investigation. Each area is divided into districts: Six in the Northern area, Two in the Southern area and Three in the Central area.

\section{DATACOLLECTION}

During the spring of 2012, sampling was carried out on a total of 11 flocks, selected at random, located in the three areas. A total of 347 non-pregnant adult female sheep varying from 2 to 6 years old, were included in this investigation and were distributed as follows: 175 for North, 122 for Centre and 50 individuals for South. All sheep were scored for 18 body measurements (quantitative) concerning with size, dimensions and weight of animals. The second type of data are thirteen coded qualitative traits (such as colour), or categorical traits (presence $=1$ or absence $=0$ ). Body measurements or quantitative traits were carried out by three technicians using Lydthin stick, tape measure and Vernier callipers. Animals were put on a flat floor and held by farmers. The 18 body measurements obtained were: head length (hl), ear length (el), ear width (ew), eye distance (ed), neck length (nl), body length (bl), trunk length (trl), pelvis length (pl), hip width (hw), chest size (cs), chest depth (cd), chest width (cw), height at withers (htw), height at sacrum (hs), height at back (hb), side depth (sd), tail length (tl) and live weight (wgt). The thirteen qualitative traits scored are as follows: head colour (hc), horn form (hf), eye form (eyf), ear form (ef), profile form (pf), fleece colour (wc), fleece extent (fe), fleece texture ( $\mathrm{ft}$ ), tail texture (tt), body conformation (bc), legs colour (lc), udder development (ud) and back form (bf).

Table III. Summary of stepwise selection of traits. (Résultats de l'analyse pas à pas).

\begin{tabular}{lcccccccc}
\hline Step & $\begin{array}{c}\text { Variables } \\
\text { Entered }\end{array}$ & $\begin{array}{c}\text { Partial } \\
\mathrm{R}^{2}\end{array}$ & F-values & $\mathrm{p}>\mathrm{F}$ & $\begin{array}{c}\text { Wilk's } \\
\text { Lamda }\end{array}$ & $\mathrm{p}<$ Lamda & ASCC & $\mathrm{p}>$ ASCC \\
\hline 1 & $\mathrm{trl}$ & 0.276 & 65.65 & $<0.0001$ & 0.724 & $<0.0001$ & 0.138 & $<0.0001$ \\
2 & $\mathrm{pl}$ & 0.211 & 45.91 & $<0.0001$ & 0.571 & $<0.0001$ & 0.218 & $<0.0001$ \\
3 & $\mathrm{htw}$ & 0.158 & 31.96 & $<0.0001$ & 0.481 & $<0.0001$ & 0.295 & $<0.0001$ \\
4 & $\mathrm{hl}$ & 0.143 & 28.35 & $<0.0001$ & 0.412 & $<0.0001$ & 0.337 & $<0.0001$ \\
5 & wgt & 0.237 & 52.92 & $<0.0001$ & 0.315 & $<0.0001$ & 0.406 & $<0.0001$ \\
6 & $\mathrm{ed}$ & 0.109 & 20.90 & $<0.0001$ & 0.280 & $<0.0001$ & 0.443 & $<0.0001$ \\
7 & $\mathrm{bl}$ & 0.093 & 17.39 & $<0.0001$ & 0.254 & $<0.0001$ & 0.469 & $<0.0001$ \\
8 & $\mathrm{cw}$ & 0.688 & 12.46 & $<0.0001$ & 0.236 & $<0.0001$ & 0.488 & $<0.0001$ \\
9 & $\mathrm{cs}$ & 0.057 & 10.18 & $<0.0001$ & 0.223 & $<0.0001$ & 0.498 & $<0.0001$ \\
\hline
\end{tabular}

Traits: trl= trunk length; pl= pelvis length; htw= height at withers; hl= head length; wgt= live weight; ed= eye distance; bl= body length; $c w=$ chest width; $c s=$ chest size.

ASCC $=$ Average squared canonical correlation. 


\section{StATISTICAL ANALYSES}

Statistical analyses were carried out using the SAS/STAT package (1999). Basic statistics for body measurements and qualitative traits were obtained using PROC UNIVARIATE and PROC FREQUENCY, respectively. The influence of the 18 measured traits was assessed using PROC MIXED, fitting a model including as fixed effects the area (with three levels: North, Center and South) and districts as a random effect nested within the area to account for non-independency of sampling in each district. Least squares means and their standard errors were obtained for each body trait by area level. Duncan'-s multiple-range test was performed on all area means of body measurement traits using PROC GLM. Stepwise discriminant procedure was applied using PROC STEPDISC to determine which morphological traits have more discriminant power than others. The CANDISC procedure was used to perform canonical analysis to derive canonical functions, linear combinations of the quantitative variables that summarize variation between areas and compute between areas Mahalanobis distance matrix. The ability of the computed canonical function to assign each individual sheep to its sampling area was calculated as the percent of correct assignment using DISCRIM procedure. The association between the qualitative traits was assessed via the correspondence analysis using the PROC CORRESP of SAS. When necessary for descriptive purposes, canonical variables and correspondence analysis dimensions were plotted using Microsoft Excel.

\section{RESULTSANDDISCUSSION}

\section{Continuoustraits}

Least squares means for the body measures analysed by environmental area are given in table I. The presented coefficient of variation varied from $4.4 \%$ to $34.3 \%$. Therefore, a large variation is shown in the body measures. Overall, the Southern area had the highest values $(\mathrm{p}<0.05)$ for 12 traits when compared to the Central area, and had the highest values for 11 traits when compared to the North sheep. The Center area had the highest values $(\mathrm{p}<0.05)$ for 10 traits when compared to the North sheep. Sheep populations are exhibiting different phenotypes according to the area. The same results were found by Dekhili et al. (2013) with goat populations in the same areas.

\section{QuALITATIVETRAITS}

Incidence in percentage of each level of the thirteen qualitative traits recorded for all individuals and for each environmental area (table II), suggests that sheep have white legs colour (100.0 \%) and horn are absent (100\%), as they have white head colour (85.88\%), with bigger eyes (98.56\%), with dropping ears (61.67\%), with right profile (99.14\%), with white fleece colour (87.61 $\%)$, with abundant fleece (70.32\%), with closed fleece $(85.88 \%)$, relatively middle tail texture $(52.16 \%)$, with middle body conformation (71.76 \%), with developed udder $(73.78 \%)$ and with right back form (77.81\%). HF and LC showed no variability but all other traits differed from each other.

\section{Multivariate analyses}

Results of the stepwise discriminant analysis are presented in table III. Nine of the eighteen measured variables were found to be highly significant $(p<0.0001)$. These are as it follows: trl, pl, htw, hl, ed, bl, wgt, $\mathrm{cw}$ and cs. All other variables were removed from the final model. The canonical analysis identified two statistically significant $(\mathrm{p}<0.0001)$ canonical variables (CAN1 and CAN2). The CAN1 and CAN2 accounted for 76 and $24 \%$ of the total variation, respectively. Figure 1, shows a bi-dimensional plot illustrating the relationship between body measurement on the $\mathrm{X}$-axis, trl and wgt are well separated from the other linear traits (hl, ed, pl, bl, cw). Although on the $\mathrm{Y}$-axis, htw, ed, cw,trl are well separated 
from the other traits (wtg, pl, hl). The between- environmental areas Mahalanobis distance matrix is given in table IV. All pairwise distances were highly significant $(\mathrm{p}<0.0001)$. The largest distance was found between the Southern and the Northern area (10.53), and 9.23 between the Centre and the South, while between the North and the Centre it was 7.59. As, the Centre is near the North and the public highway of communications are present this facilitates easily the exchange of rams between breeders or to buy rams from the market. The hypotheses that area's means are equal in the population analyzed were tested using Wilk's Lamda. This had a significant value $(\mathrm{p}<0.0001)$ of $0.16268736(\mathrm{~F}=25.38$; degree of freedom 38) showing clearly, that differences found between areas were statistically different from zero. Phenotypic differences are present among populations, which are the result of geographical
Table IV. Mahalanobis distance between sheep populations sampled in each environmental area. (Distances de Mahalanobis entre les populations de mouton échantillonnées dans chaque milieu).

\begin{tabular}{lcc}
\hline Area & Central & Southern \\
Northern & $7.59^{\star \star \star}$ & $10.53^{\star \star \star}$ \\
Southern & $9.23^{\star \star \star}$ & - \\
\hline$\star \star \star p<0.0001$. & & \\
\hline
\end{tabular}

locations or long distances. These phenotypic differences could be maintained by the reduction of gene flow. Adaptive divergence in morphological traits was higher between North population and South one and between South and Central population and lower between North and Central sheep. This indicates that small genetic exchange has taken place overtime

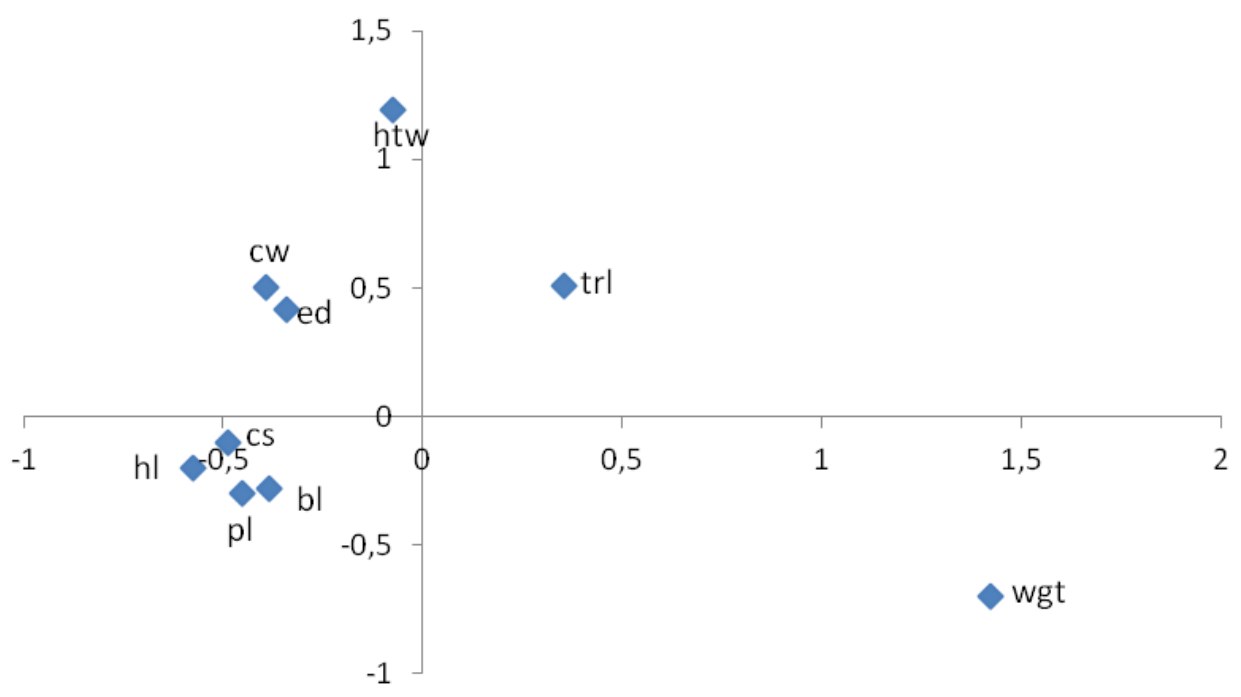

Figure 1. Bi-dimensional plot illustrating the association between body measures in Sétif sheep assessed via canonical analysis. Traits: hl, head lenght; ed,eye distance; bl, body lenght; trl, trunk lenght; pl, pelvis lenght; cs, chest size; cw, chest width; htw, height at withers; wgt, live weight. (Figure bidimensionnelle représentant l'association des mesures corporelles à Sétif a travers l'analyse canonique). 
between the latter has reduced the genetic distance and was facilitated by geographical relative proximity. Adaptive divergence in the morphological traits was higher between the three sheep-populations. Adding to the difference in distance between locations,

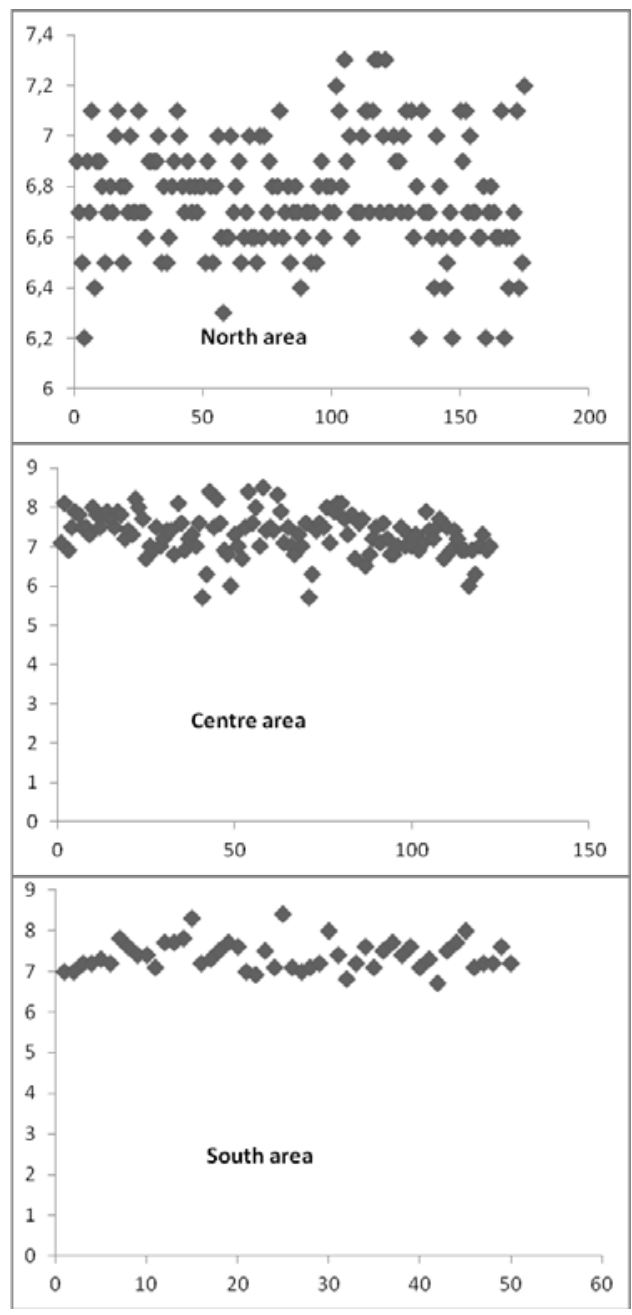

Figure 2. Bi-dimensional representation of the canonical traits associated with individuals sampled in each of the environmental areas of Sétif. (Figure bidimensionnelle représentant les variables canoniques associées avec les individus échantillonnés dans le milieu de Sétif). one second point has to be pointed out, is the use of males for many years in the same flock, the kind of selection based mainly on visual qualitative traits, the probable resulting inbreeding depression, migration is excluded between each population, might have been the main raison of this difference between populations and at the same time the similarity within population. Random drift may occur independently in these different populations leading to this genetic differentiation between populations. From these factors cited above, the whole Sétif sheep-population is being subdivided into local groups or sub-populations, and these differ in genetic constitution. The values computed for CAN1 and CAN2 for each individual were plotted by environmental area (figure 2). All individuals in the North area are well spread and distant from each other, showing a real heterogeneity between individuals, wide variation intra population is found in North. On the contrary, for the others locations, individuals are more or less clustered in the same line on the $\mathrm{X}$-axis, where individuals are really more homogeneous showing less variation intra population. In this respect, the discriminant analysis carried out gave more information (table IV). Most of the individuals within the area were classified (table $\mathbf{V}$ ) into their source population (North: 74.59\%; Centre:

Table V. Percentage of classification into environmental area for sheep individual sampled, according to the environmental area of sampling, using morphological structural traits and discriminant analysis. (Pourcentage de classification des individus échantillonnés dans chaque site selon le milieu pour les variables de structures et l'analyse discriminante).

\begin{tabular}{lccc}
\hline Area & Northern & Central & Southern \\
\hline Central & 74.59 & 14.75 & 10.66 \\
Southern & 6.00 & 84.00 & 10.00 \\
Total & 27.09 & 18.73 & 54.18 \\
\hline
\end{tabular}


$84.0 \%$; South: $97.0 \%$ ). A small part of the individuals was erroneously cross classified. Correspondence analysis carried out on the thirteen qualitative traits recorded showed that six of them (ef, wc, fe, tt, ud and bf) explained 65 percent of the inertia. Therefore, the analysis was re-run using only these six traits where figure 3 shows the values computed for the two identified dimensions for each environmental area. Here again, a intra-variation is well pictured for the three areas. Where in North we can see two not clustered and distinct groups of individuals, and a clear intra-variation is present for the two other areas. The first and second dimensions identified explained respectively, 95.1 and $4.9 \%$ of the total variation. For the qualitative traits, results of the Chi-squared test showed that incidence of the analyzed traits varied significantly $(\mathrm{p}<0.05)$ among environmental areas (table II), saying a certain intravariation is existing between flocks and intra-area concerning these traits.

Animal genetic resources are a part of biological diversity and are important in any development programme. Between breed diversity is considered as an important criterion to be considered when ordering priorities for conservation of breeds. As we know, phenotypes are an expression of genetic characteristics under environmental conditions; therefore, phenotypic variance is influenced by genetic variance and environmental one. Further characterization using genetic analyses would be helpful and necessary. The present results showed significant morphological variation among all three sheep populations in the three areas. This intra-area homogeneity found could be because of the environmental conditions in which sheep populations are bred. This might indicate a certain relationship between phenotype constitution intra-area, adding to this the combination of the same set of genes and geographical differences (Dekhili et al., 2013).

\section{CONCLUSION}

Significant morphological variation was found among the three sheep populations of Sétif. This investigation showed that trl,

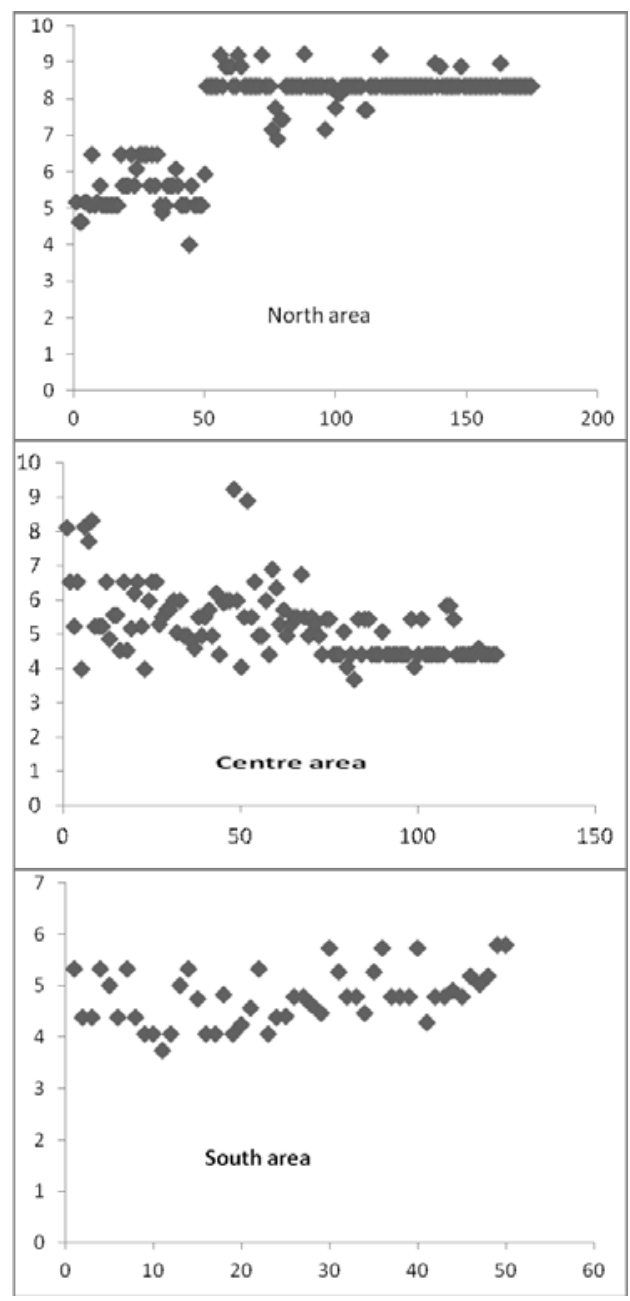

Figure 3. Bi-dimensional representation of the individuals sampled in each of the environmental areas of Sétif via correspondence analysis for 6 qualitative traits. (Figure bidimensionnelle représentant les individus échantillonnés dans chaque milieu de Sétif à travers l'analyse des correspondances pour 6 variables qualitatives). 


\section{A MORPHOMETRIC STUDY OF SHEEP REARED IN NORTH-EAST ALGERIAN}

pl, htw, hl, ed, bl, wgt, cw and cs were the most discriminant variables to separate the three sheep populations between areas. These results would aid further to the characterization, management and improvement of the Algerian sheep. However, more solid characterization using protein and microsatellite markers are needed as complements. The absence, since a long time, of systematic improvement programme constitutes a serious threat to sheep

\section{REFERENCES}

Chellig, R. 1992. Les races ovines algériennes. Office des Publications Universitaires. Alger.

Dekhili, M. et Aggoun, A. 2007. Performances reproductives de brebis de race Ouled-Djellal dans deux milieux contrastés. Arch Zootec, 56: 963-966.

Dekhili , M.; Bounechada, M. and Manallah, I. 2013. Multivariate analyses of morphological traits in Algerian goats, Sétif, north-eastern Algeria. Anim Genet Resourc Inf, 52: 51-57.

Delgado, J.V.; Barba, C.; Camacho, M.E.; Sereno, F.T.P.S.; Martinez, A. and Vega Pla, J.L. 2001. Caracterización de los animales domésticos en España. Anim Genet Resourc Inf, 29: 7-18.

Legaz, E.; Cervantes, I.; Perez-Cabal, M.A.; De la Fuente, L.F.; Martinez, R.; Goyache, F. and Gutiérrez, J.P. 2011. Multivariate characterization of morphological traits in Assaf (Assaf. E) sheep. Small Ruminant Res, 100: 122-130.

SAS. 1999. SAS/STAT: User's guide, release 8.2. SAS institute Inc. Cary, NC. USA. from a conservation point of view and immediate action is required. However, Algerian sheep is still contributing substantially to the income of the farmers, but until when?.

\section{ACKNOWLEDGEMENTS}

The authors thank the management and the technicians of the animal production laboratory for carrying out this work.

Traoré, A.;Tamboura, H.H.; Kabore, A.; Royo, L.J.; Fernandez, I.; Alvarez, I.; Sangare, D.; Bouchel, D.; Poivey, J.P.; Francois, D.; Oguyeni, A.; Sawadogo, L. and Goyache, F. 2008a. Multivariate characterization of morphological traits in Burkina Faso sheep. Small Ruminant Res, 80: 62-67.

Traoré, A.; Tamboura, H.H.; Kabore, A.; Royo, L.J.; Fernandez, I.; Alvarez, I.; Sangare, D.; Bouchel, D.; Poivey, J.P.; Francois, D.; Sawadogo, L. and Goyache, F. 2008b. Multivariate analyses on morphological traits of goats in Burkina Faso. Arc Tierz Dummerstorf, 51: 588-600.

Yakubu, A. 2011. Multivariate analysis of morphostructural characteristics in Nigerian indigenous sheep. S Afr Anim Sci, 6: 1-4.

Yakubu, A.; Salakpo, A.E.; Imumorin, I.G.; Ige, A.O. and Akinyemi, M.O. 2010. Discriminant analysis of morphometric differentiation in the West African Dwarf and Red Sokoto goats. Afr $\mathrm{J}$ Anim Sci, 4: 40. 